Фармакологічні дослідження біологічно активних речовин Pharmacological researches of biologically active substances

Рекомендована д. мед. наук, профр. О. М. Олещук

УДК $619: 615.281 .9$

DOI 10.11603/2312-0967.2018.1.8694

\title{
ВИВЧЕННЯ ГОСТРОЇ ТОКСИЧНОСТІ ПРЕПАРАТУ АРГОЦИД ПРИ ВНУТРІШНЬООЧЕРЕВИННОМУ ВВЕДЕННІ
}

\author{
(c) Ж. М. Полова ${ }^{1}$, Н. М. Серединська \\ Національний медичний університет імені О. О. Богомольця ${ }^{1}$ \\ Інститут фрармакології та токсикології НАМН України ${ }^{2}$, Київ \\ zpolova@ukr.net
}

\begin{abstract}
Мета роботи. Вивчення гострої токсичності ветеринарного препарату Аргоцид, розчин для інтрацистернального введення, при внутрішньоочеревинному введенні статевозрілим білим щурам.

Матеріали і методи. Об'єктом дослідження були серії препарату Аргоцид, який містить цитрат срібла, D- пантенол та L- аргінін, призначений для лікування субклінічного маститу великої рогатої худоби. Дослідження гострої токсичності тест-зразків препарату Аргоцид проводили у дослідах на білих нелінійних статевозрілих щурах обох статей, віповідно до вимог, що висувають до потенційних ліків. Випробування проведені при внутрішньочеревному введенні препарату в різних дозах - від 2,0 до 6,3 мл / кг. Статистична обробка даних була виконана з використанням t-критерію Стьюдента. Для статистичної обробки даних використано програму MS Excel.

Результати й обговорення. У результаті дослідження гострої токсичності препарату Аргоцид встановлено, що інтегральні показники життєдіяльності тварин - маса та температура тіла не зазнавали суттєвих індивідуальних змін вподовж 14 діб спостереження після одноразового внутрішньоочеревинного введення. При досліджені дози препарату у діапазоні від 1,58 мл/кг маси тіла тварини до 5,0 мл/кг визначено, що жодного випадку загибелі тварин не зареєстровано за внутрішньоочеревинного введення препарату у будь-якій дозі. При застосуванні препарату у дозах 2,5 мл/кг та вище у тварин проявилися клінічні ознаки інтоксикації відразу після введення препарату, що може бути пов'язано з подразненням очеревини. Через 3 доби після внутрішньоочеревинного застосування Аргоциду жодних клінічних ознак інтоксикації не спостерігали.

Висновки. Аналіз отриманих даних дозволяє віднести препарат Аргоцид, розчин для інтрацистернального введення за ступенем небезпеки до відносно нешкідливих препаратів (VI клас) оскільки середня летальна доза перевищує 3,0 мл/кг маси тіла тварини за внутрішньоочеревинного введення.
\end{abstract}

Ключові слова: доклінічні дослідження; ветеринарний препарат; внутрішньоочеревинне введення; гостра токсичність; Аргоцид.

Вступ. В Україні визначено стратегію руху до Європейського Союзу, яка передбачає удосконалення вітчизняного нормативного забезпечення щодо виробництва і контролю якості ліків до стандартів, прийнятих в ЄС. Фармацевтична промисловість у Європейському Союзі працює згідно 3 високими стандартами щодо управління якістю при розробці, виробництві та контролі. Система видачі торгових ліцензій передбачає проходження всіма лікарськими засобами та ветеринарними препаратами лз та ВП експертизи у компетентних уповноважених органах, щоб гарантувати їхню відповідність сучасним вимогам щодо безпеки, якості й ефективності. Система ліцензування виробництва гарантує, що вся продукція, дозволена для продажу на Європейських ринках ЛЗ та ВП, виготовлена лише виробниками, що мають відповідні ліцензії, чия діяльність регулярно інспектується компетентними уповноваженими органами із застосуванням принципів управління ризиками для якості. Ліцензії на виробництво є обов'язковими для всіх фрармацевтичних виробників в ЄС незалежно від того, де реалізується продукція - на території ЄС, чи за його межами [1, 2].

Однією з важливих умов виробництва ветеринарних препаратів (ВП) є забезпечення якості, в першу чергу, шляхом впровадження принципів і правил належних практик. Сьогодні основний рівень вимог щодо контролю якості препаратів диктує міжнародний стандарт GLP (належна лабораторна практика). За цим стандартом здійснюються первинні токсикологічні дослідження і фрармакологічна оцінка нових лікарських речовин, їх окремих компонентів, різних форм нових ветеринарних препаратів, які визначають успішний розвиток подальших експериментальних, клінічних досліджень та мають вирішальний вплив на можливість створення високоефективного конкурентоспроможного, малотоксичного безпечного препарату, не здатного викликати побічної дії і віддалені наслідки [3].

Дана робота $€$ продовженням наукового дослідження щодо теоретичного та експериментального

ISSN 2312-0967. Pharmaceutical review. 2018. № 1 
обґрунтування складу та технології лікарських препаратів антимікробної дії для застосування у ветеринарії (в рамках науково-дослідної роботи кафедри управління та економіки фрармації з технологією ліків Тернопільського державного медичного університету імені І. Я. Горбачевського на тему «Маркетингові, фрармакоекономічні і технологічні дослідження зі створення лікарських засобів» (№ державної реєстрації 0115U001530) [4,5].

Мета роботи - вивчення гострої токсичності ветеринарного препарату Аргоцид, розчин для інтрацистернального введення, при внутрішньоочеревинному введенні статевозрілим білим щурам.

Матеріали і методи. Дослідження проводили в IHституті фрармакології і токсикології Національної академії медичних наук України (м. Київ). Експерименти, в яких використовували тварин, проводили відповідно до Міжнародних вимог про гуманне ставлення до тварин і виконанням вимог Директиви 86/609 / ЄЕС щодо питання захисту тварин [6, 7]. Об'єктом дослідження були серії комбінованого препарату Аргоцид, що містить цитрат срібла, D - пантенол та L - аргінін та призначений для лікування субклінічного маститу великої рогатої худоби. Дослідження гострої токсичності тест-зразків препарату Аргоцид, розчин для інтрацистернального введення, проводили у дослідах на білих нелінійних статевозрілих щурах обох статей, відповідно до вимог, що висувають до потенційних ліків $[8,9]$.

В експериментах використано здорові тварини відповідної маси. Коливання маси тіла у відповідних групах не перевищували \pm 10 \%. Самиці використовували віргільні та невагітні. Тварин утримували групами за статевою ознакою в клітках не більше 6 особин в кожній для забезпечення можливості візуального огляду кожної тварини.

Після отримання 3 віварію кожна тварина була оглянута кваліфікованим ветеринаром з метою визначення стану здоров'я. Тварини були поміщені до полікарбонатних кліток розміром 660×370×140 мм 3 кришкамиізоцинкованоїсталірозміром550×320×180 мм, що комплектувалися скляними пляшками для води. В кімнатах для утримання тварин дотримувалися таких умов: температура - (20-24) ${ }^{\circ} \mathrm{C}$, вологість повітря - (30-70) \%, цикл освітлення - 12 год світло/12 год темрява. Всім щурам згодовувався ad libitum стандартний раціон для лабораторних тварин, що постачався фрірмою «Phoenix» («Фенікс»), Україна. Вода із міської водопровідної мережі (після оберненого осмосу і стерилізації УФ-випромінюванням) надавалась тваринам ad libitum. У якості підстилки використовували тирсу вільхи (Alnus glutinosa), попередньо оброблену автоклавуванням. Всі білі щури були зважені, пронумеровані, позначені з використанням розчину діамантового зеленого (1\% спиртовий розчин) i поміщені в клітки для акліматизації протягом 7 діб у лабораторному приміщенні. За 24 год до ведення тест-зразка щури були оглянуті кваліфікованим ветеринаром з метою визначення стану здоров'я, зважені, рандомізовані [10].

При дослідження гострої токсичності у дослідах на щурах було застосовано два шляхи введення препарату, як адекватні досліджуваній лікарській формі (інтрацистернальний розчин) та такі, що можуть бути використані за очікуваного клінічного застосування - внутрішньом'язовий та внутрішньоочеревинний. Результати гострої токсичності препарату Аргоцид при внутрішньом'язовому введені описані в окремій статті.

Препарат у лікарській фрормі розчин вводили у різних дозах - від 2,0 до 6,3 мл/кг. Об'єм рідини, що вводився тваринам, не перевищував допустимі об'єми, визначені правилами доклінічного дослідження лікарських засобів [11]. До окремих груп тварин (контрольних) входили тварини, яким вводили розчинник (носій) препарату - воду для ін'єкцій, що застосовувалася в об'ємі 1,5 мл внутрішньоочеревинно.

Для розрахунку середньої летальної дози існує чимало статистичних методів, які за фрактично однакової точності вимагають різних матеріальних, фрінансових та фрізичних витрат. Найбільш оптимальним серед таких методів вважають метод найменших квадратів, оскільки дозволяє на найменшій кількості лабораторних тварин вирахувати не лише середню летальну дозу речовини, а й параметри її вірогідності [11].

Тривалість спостереження за станом тварин після одноразового введення Аргоциду у лікарській формі розчин для інтрацистернального введення становила 14 діб. Основним критерієм токсичної дії препарату була загибель тварин. Водночас у тварин протягом 14 діб реєстрували дані про можливий дозозалежний вплив препарату на різні функції організму: індивідуальну масу тіла тварин, загальний стан, зміни положення тіла, стан шкіри, колір слизових оболонок, температуру (ректальну) тіла, наявність/відсутність міозу/мідріазу, лакримації, салівації, ринореї, зміни кольору сечі та фекалій та їх частоти, сонливість, наявність тремору, судом, пілоерекція, діяльність серцево-судинної, центральної нервової та дихальної систем.

Спостереження за проявами клінічних ознак токсичності і загибелі тварин проводили у перший день після введення препарату Аргоцид, розчин для інтрацистернального введення, протягом першої години безперервно, а потім через 2, 3, 5 год після введення. Протягом наступних 14 днів кожну тварину обстежували щоденно, двічі на день о $10^{00}$ та о $17^{00}$. Реєструвались випадки виникнення та/або зникнення клінічних ознак токсичності, в тому числі - загибелі тварин.

Індивідуальну масу тіла тварин реєстрували до $10^{00}$ перед уведенням препарату, а потім через 3, 7 і 14 днів після введення препарату Аргоцид, розчин для інтрацистернального введення. Зміни маси тіла

ISSN 2312-0967. Фармацевтичний часопис. 2018. № 1 
Фармакологічні дослідження біологічно активних речовин

Pharmacological researches of biologically active substances

були розраховані порівняно до маси на день введення та масою тіла тварин контрольних груп.

Макроскопія. Через 14 днів після введення препарату Аргоцид, розчин для інтрацистернального введення, усі тварини були знеживлені шляхом цервікальної дислокації під легким ефрірним наркозом. Усі знеживлені в кінці дослідження тварини підлягали повному зовнішньому огляду, розтину з урахуванням зареєстрованих клінічних порушень і детальному дослідженню внутрішніх органів. Перед знеживленням в кінці експерименту всі тварини голодували протягом 3-х годин. Передбачалося проведення макроскопічного дослідження тварин, які можуть загинути, відразу після встановлення фракту загибелі або вранці наступної доби (об $11^{00}$ ), якщо тварина гинула вночі.

Маса органів. Були зважені наступні органи: печінка, нирки, селезінка, легені, серце. Парні органи були зважені разом. Відносна маса органів розраховувалась у грамах на 100 г маси тіла.

Дані наведені як середнє значення \pm похибка середнього (M $\pm \mathrm{m})$. Статистична обробка даних була виконана 3 використанням t-критерію Стьюдента. Зміни вважалися статистично значущими при $p<0,05$. Для статистичної обробки даних була використана програма MS Excel $[12,13]$.

Результати й обговорення. У попередніх дослідженнях ми з'ясували, що встановлення величини середньої летальної дози (ЛД розчин для інтрацистернального введення, при внутрішньом'язовому одноразовому введенні білим статевозрілим щурам унеможливлене через відсутність загибелі тварин навіть при застосуванні препарату у дозах, що перевищують 5,0 мл/кг.

За результатами аналізу даних експерименту щодо внутрішньочеревного введення препарату встановлено, що інтегральні показники життєдіяльності тварин - маса та температура тіла не зазнавали суттєвих індивідуальних змін впродовж 14 діб спостереження після одноразового внутрішньоочеревинного введення Аргоциду. Встановлено фрізіологічний приріс маси тіла у тварин. Результати представлено у таблиці 1. Тварини дослідної та контрольної груп набирали масу відповідно до срізіологічної норми.

Досліджували дози препарату у діапазоні від 1,58 мл/кг маси тіла тварини до 5,0 мл/кг. Визначено, що жодного випадку загибелі тварин не зареєстровано за внутрішньоочеревинного введення препарату у будь-якій дозі. Результати представлено у таблиці 2.

При внутрішньоочеревинному введенні білим щурам препарату Аргоцид у лікарській фрормі розчин для інтрацистернального введення, що був застосований у дозах 2,5 мл/кг та вище, у тварин почали проявлятися клінічні ознаки інтоксикації відразу після введення препарату. Тварини були в'ялими, малорухливими, скупченими у клітці, зі зниженою реакцією на зовнішні подразники. Дані симптоми спостерігалися впродовж 2-х діб після внутрішньоочеревинного введення Аргоциду. Витягування задніх кінцівок у тварин за намагання пересуватися у клітці фріксувалося також впродовж 2-х діб після застосування препарату у тварин, які отримували його в дозах 2,5 мл/кг, 3,16 мл/кг, 3,98 мл/кг та 5,0 мл/кг. Атаксію спостерігали впродовж перших двох годин після одноразового введення препарату у тварин усіх дослідних груп. Більш активні рухові реакції спостерігалися у тварин, яким було введено препарат у дозах $(2,0-3,16)$ мл/кг через 5 год після введення препарату. Подібна реакція тварин на внутрішньоочеревинне уведення роз-

Таблиця 1. Динаміка маси та температури тіла $(\mathrm{M} \pm \mathrm{m})$ у статевозрілих білих щурів після одноразового внутрішньоочеревинного введення препарату Аргоцид, розчин для інтрацистернального введення

\begin{tabular}{|c|c|c|}
\hline \multirow{2}{*}{ Група } & \multicolumn{2}{|c|}{ Термін спостереження } \\
\hline & вихідні дані & 14-та доба \\
\hline Контроль, маса, г (n=6) & $199,0 \pm 1,4$ & $214,2 \pm 1,7^{*}$ \\
\hline Контроль, температура, ${ }^{\circ} \mathrm{C}(\mathrm{n}=6)$ & $38,1 \pm 0,14$ & $38,0 \pm 0,09$ \\
\hline Дослід, маса, г (n=24) & $198,6 \pm 1,8$ & $211,5 \pm 2,8^{*}$ \\
\hline Дослід, температура, ㅇ C (n=24) & $38,0 \pm 0,11$ & $38,2 \pm 0,12$ \\
\hline
\end{tabular}

Примітка. * - p<0,05 відносно вихідних даних.

Таблиця 2. Дослідження гострої токсичності Аргоциду у лікарській фрормі розчин для інтрацистернального введення у дослідах на білих статевозрілих щурах при внутрішньоочеревинному введенні

\begin{tabular}{|c|c|c|c|c|c|c|}
\hline \multirow{2}{*}{ Стать тварин } & \multicolumn{5}{|c|}{ Доза препарату Аргоцид, мл/кг } \\
\cline { 2 - 7 } & 1,58 & 2,0 & 2,5 & 3,16 & 3,98 & 5,0 \\
\hline Самиці & $0 / 2^{*}$ & $0 / 2$ & $0 / 2$ & $0 / 2$ & $0 / 2$ & $0 / 2$ \\
\hline Самці & $0 / 2$ & $0 / 2$ & $0 / 2$ & $0 / 2$ & $0 / 2$ & $0 / 2$ \\
\hline
\end{tabular}

Примітка. * - відношення кількості загиблих тварин до кількості тварин у групі на зазначену дозу препарату.

ISSN 2312-0967. Pharmaceutical review. 2018. № 1 
Фармакологічні дослідження біологічно активних речовин Pharmacological researches of biologically active substances

чину Аргоциду може бути пов'язана з подразненням власне очеревини.

До третьої доби після введення препарату у тварин усіх дослідних груп був неохайний зовнішній вигляд, на вигляд - вологий, настовбурчений, шерстний покрив, водночас споживання їжі та води були звичайними. Інших ознак інтоксикації - судом, тремору, салівації, зміни частоти дихання, синюшності видимих слизових оболонок, блефароспазму, бокового положення тощо - у тварин не відзначалося.

Через 3 доби після внутрішньоочеревинного застосування Аргоциду жодних клінічних ознак інтоксикації не спостерігали: тварини охоче споживали корм та воду, реакції на зовнішні подразники були звичайними, ресрлекси збережені, тварини активно рухалися, мали охайний зовнішній вигляд, навіть за введення високих доз препарату - до 5,0 мл/кг маси тіла тварини. Вочевидь, відновлення рухових реакцій, відсутність витягування задніх кінцівок під час пересування у клітці через зазначений термін після введення препарату $€$ підтвердженням висловленого вище передбачення щодо короткотривалого подразнення саме очеревини.

Серед тварин контрольної групи при внутрішньоочеревинному введенні Аргоциду загибелі не зареєстровано, їхні поведінкові, вегетативні фрункції - без змін. Всі контрольні тварини (n=6) були активні, мали гладеньку шерсть та чисту шкіру, активно рухалися та споживали корм та воду.

Макроскопічні дослідження. Проведено патоморорологічне дослідження органів і тканин білих статевозрілих щурів обох статей, що вижили і були піддані евтаназії через 14 діб спостереження, яким одноразово внутрішньоочеревинно вводили препарат Аргоцид у лікарській фрормі розчин для інтрацистернального введення у різних дозах.

При зовнішньому огляді тварин ознак патологічних змін не виявлено, шерсть та шкірні покрови чисті, підшкірний шар жирової тканини виражений помірно, на слизових оболонках та шкірі уражень не спостерігалося. Очі, ніс, губи, ротова порожнина, анальний отвір та зовнішні статеві органи без ознак ураження у всіх тварин дослідних груп.

При розтині дослідних статевозрілих тварин серозні оболонки черевної, плевральних та навколосерцевої порожнини гладенькі, блискучі, без ознак ушкодження та запалення, кількість вільної серозної рідини в порожнинах не збільшена. Органи черевної порожнини, а також власне очеревина, на що осо- бливо зверталася увага, зважаючи на шлях уведення Аргоциду, були звичайної консистенції та кольору.

У групах контрольних та дослідних тварин не виявлено альтеративних, запальних та гемодинамічних порушень у різних органах та тканинах.

Аналіз отриманих даних дозволяє віднести препарат Аргоцид, розчин для інтрацистернального введення 3 огляду на останню класифікацію хімічних речовин за ступенем небезпечності (за ГОСТ 12.1.007.76 «Шкідливі речовини. Класифрікація та загальні вимоги нешкідливості») та за класифрікацією К. К. Сидорова до відносно нешкідливих препаратів (VI клас) через те, що середня летальна доза перевищує 3,0 мл/кг маси тіла тварини при внутрішньоочеревинному введенні $[8,14]$.

Висновки. 1. Проведено дослідження гострої токсичності інтрамамарного ветеринарного препарату під умовною назвою Аргоцид, у вигляді лікарської срорми - розчин для інтрацистернально введення. Випробування проведено на білих нелінійних статевозрілих щурах обох статей при внутрішньочеревному введенні в різних дозах - від 2,0 до 6,3 мл / кг.

2. Аналіз отриманих даних засвідчив, що інтегральні показники життєдіяльності тварин - маса та температура тіла не зазнавали суттєвих індивідуальних змін вподовж 14 діб спостерігали після одноразового внутрішньоочеревинного введення Аргоциду. Відмічений фрізіологічний приріс маси тіла у тварин.

3. При досліджені дози препарату у діапазоні від 1,58 мл/кг маси тіла тварини до 5,0 мл/кг визначено, що жодного випадку загибелі тварин не зареєстровано при внутрішньоочеревинному введенні препарату у будь-якій дозі.

4. При внутрішньоочеревинному введенні білим щурам препарату Аргоцид в лікарській формі розчин для інтрацистернального введення, що був застосований у дозах 2,5 мл/кг та вище, у тварин почали проявлятися клінічні ознаки інтоксикації відразу після введення препарату, що може бути пов'язано з подразненням власне очеревини. Через 3 доби після внутрішньоочеревинного застосування Аргоциду жодних клінічних ознак інтоксикації не спостерігали.

5. Аналіз отриманих даних дозволяє віднести препарат Аргоцид, розчин для інтрацистернального введення за ступенем небезпечності до відносно нешкідливих препаратів (VI клас) через те, що середня летальна доза перевищує 3,0 мл/кг маси тіла тварини при внутрішньоочеревинному введенні.

ISSN 2312-0967. Фармацевтичний часопис. 2018. № 1 
Фармакологічні дослідження біологічно активних речовин Pharmacological researches of biologically active substances

\title{
ИЗУЧЕНИЕ ОСТРОЙ ТОКСИЧНОСТИ ПРЕПАРАТА АРГОЦИД ПРИ ВНУТРИБРЮШИННОМ ВВЕДЕНИИ
}

\author{
Ж. Н. Полова ${ }^{1}$, Н. Н. Серединская² \\ Национальный медицинский университет имени А. А. Богомольця ${ }^{1}$, Киев \\ Институт фрармакологии и токсикологии АМН Украины ${ }^{2}$, Киев \\ zpolova@ukr.net
}

Цель работы. Изучение острой токсичности ветеринарного препарата Аргоцид, раствор для интрацистернального введения, при внутрибрюшинном введении половозрелым белым крысам.

Материалы и методы. Объектом исследования были серии комбинированного препарата Аргоцид, содержащего цитрат серебра, D-пантенол и L-аргинин для лечения субклинического мастита крупного рогатого скота. Исследование острой токсичности проводилось в опытах на белых нелинейных половозрелых крысах обоего пола, согласно требованиям, предъявляемым к потенциальным лекарствам. Испытания были проведены при внутрибрюшинном введении препарата в различных дозах - от 2,0 до 6,3 мл / кг. Статистическая обработка данных была выполнена с использованием t-критерия Стьюдента. Для статистической обработки данных была использована программа MS Excel.

Результаты и обсуждение. В результате исследования острой токсичности препарата Аргоцид установлено, что интегральные показатели жизнедеятельности животных - масса и температура тела не испытывали существенных индивидуальных изменений в течении 14 суток наблюдения после однократного внутрибрюшинного введения. При исследовании доз в диапазоне от 1,58 мл / кг массы тела животного до 5,0 мл / кг определено, что ни одного случая гибели домашних животных не зарегистрировано при внутрибрюшинном введении препарата в любой дозе. При применении препарата в дозах 2,5 мл / кг и выше у животных проявлялись клинические признаки интоксикации сразу после введения препарата, что может быть связано с раздражением брюшины. Через 3 суток после внутрибрюшинного применения Аргоцида никаких клинических признаков интоксикации не наблюдалось.

Выводы. Анализ полученных данных позволяет отнести препарат Аргоцид, раствор для интрацистернального введение по степени безопасности к относительно безвредным препаратам (VI класс) поскольку средняя летальная доза превышает 3,0 мл / кг массы тела животного при внутрибрюшинном введении.

Ключевые слова: доклинические исследования; ветеринарный препарат; внутрибрюшинное введение; острая токсичность; Аргоцид.

\section{ACUTE TOXICITY STUDY OF ARGOCIDE DRUG WHEN ADMINISTERED INTRAPERITONEALLY}

\author{
Zh. N. Polova ${ }^{1}$, N. N. Seredinskaya ${ }^{2}$ \\ O. Bohomolets National Medical University ${ }^{1}$, Kyiv \\ Institute of Pharmacology and Toxicology of NAMS of Ukraine ${ }^{2}$, Kyiv \\ zpolova@ukr.net
}

The aim of the work. Study of acute toxicity of the veterinary drug Argocide - solution for intracisternal administration with intraperitoneal administration to sexually mature white rats.

Materials and Methods. The object of the study was a series of a combined drug of Argocide containing silver citrate, D-panthenol and L-arginine for the treatment of subclinical mastitis in cattle. The acute toxicity study was carried out in experiments on white non-linear sexually mature rats of both sexes, according to the requirements for potential drugs. The tests were performed with intraperitoneal administration of the drug in various doses - from 2.0 to $6.3 \mathrm{ml} / \mathrm{kg}$. Statistical processing of data was performed using Student t-test. For the statistical processing of data, the MS Excel program was used.

Results and Discussion. As a result of the study of acute toxicity of Argocide, it was established that integral indices of animal life - weight and body temperature did not undergo significant individual changes during 14 days of observation after single intraperitoneal administration. In studies of doses ranging from $1.58 \mathrm{ml} / \mathrm{kg}$ body weight of the animal to $5.0 \mathrm{ml} / \mathrm{kg}$, it is determined that no case of death of domestic animals has been recorded with intraperitoneal administration of the drug at any dose. When using the drug in doses of $2.5 \mathrm{ml} / \mathrm{kg}$ and above, the animals showed clinical signs of intoxication immediately after the administration of the drug, which may be due to irritation of the peritoneum. Three days after the intraperitoneal administration of Argocide, no clinical signs of intoxication were observed.

Conclusions. The analysis of the obtained data allows to classify the Argocide drug, the solution for intracisternal injection according to the degree of safety to relatively harmless preparations (VI class), since the average lethal dose exceeds $3.0 \mathrm{ml} / \mathrm{kg}$ of body weight of the animal with intraperitoneal administration.

Key words: preclinical research; veterinary drug; intraperitoneal administration; acute toxicity; Argocide.

ISSN 2312-0967. Pharmaceutical review. 2018. № 1 
Фармакологічні дослідження біологічно активних речовин Pharmacological researches of biologically active substances

\section{Список літератури}

1. Методичні рекомендації щодо основних правил належної практики виробництва та контролю якості ветеринарних препаратів. - [Електронний ресурс]. Режим доступу: http://www.vet.gov.ua/node/1819.

2. Виробництво ветеринарних препаратів за принципами належної виробничої практики (GMP) - стратегія гарантії якості та відповідності до вимог міжнародних стандартів. / Ю.М.Косенко, Л. Є. Зарума, Л.В.Калиновська [та ін.] // Науково-технічний бюлетень Інституту біології тварин і Державного науково-дослідного контрольного інституту ветпрепаратів та кормових добавок. - 2014. - № 2 - 3. - C. 340-345.

3. Про затвердження Порядку проведення доклінічного вивчення лікарських засобів та експертизи матеріалів доклінічного вивчення лікарських засобів. «Експериментальне вивчення токсичної дії потенційних лікарських засобів». [Електронний ресурс]: наказ МОЗ України № 944 від 14.12.2009. - Режим доступу http:// zakon2.rada.gov.ua/laws/show/z0053-10. Назва з екрану 4. Polova Z. Development of the composition of intramammary combined preparation based on silver citrate for veterinary / Z. Polova, L. Almakayeva, T. Nehoda // Czech and Slovak Pharmacy. - 2017 - No. 66 (5) - P. 227-233.

5. Полова Ж. М. Вивчення токсикологічних властивостей цитрату срібла як активного фрармацевтичного інгредієнта / Ж. М. Полова, І. В. Саханда, О. П. Долайчук // Збірник наукових праць співробітників НМАПО імені П. Л. Шупика. - 2016. - № 24 (4). - С. 290-295.

6. Council Directive 2010/63/EU of 22 September 2010 on the protection of animals used for scientific purposes // Official Journal of the European Communities. - 2010. - L 276. - P. 33-79.

7. Порядок проведення науковими установами дослідів, експериментів на тваринах // Офріційний вісник України.
- Офріц. вид. - 2012 р. - № 24. - С. 82. - (Нормативний документ Міністерства освіти, науки, молоді та спорту України. Наказ від 01.03.2012 № 249).

8. Доклінічні дослідження ветеринарних лікарських засобів / І. Я. Коцюмбас, О. Г. Малик, І. П. Патерега та ін.; за ред. І. Я. Коцюмбаса. - Львів : Тріада плюс, 2006. - 360 с.

9. Доклінічні дослідження лікарських засобів : метод. реком. / за ред. О. В. Стефранова; Держ. фрармакол. центр. - Київ, 2001. - 527 с.

10. Положення про Комітет з питань етики (біоетики) / (Нормативний документ Міністерства освіти, науки, молоді та спорту України: наказ від 19.11.2012 № 1287): Нормативно-правова база Міністерства освіти і науки України (офріційний веб-сайт) [Електронний ресурс] / Режим доступу до документу: http://www.mon.gov.ua/ua/ activity/63/64/normativno-pravova-baza/.

11. Експериментальне вивчення токсичної дії потенційних лікарських засобів // Доклінічні дослідження лікарських засобів: [метод. рек.] / В. М. Коваленко, О. В. Стефанов, Ю. М. Максимов, І. М. Трахтенберг [за ред. : член-кор. АМН України О. В. Стефанова]. - К. : Авіцена, 2001. - С. 74-97.

12. Прозоровский В. Б. Статистическая обработка результатов фрармакологических исследований / В. Б. Прозоровский // Психофрармакология и биологическая наркология. - 2007. - Т. 7. - Вып. 3-4. - С. 2090-2120.

13. Реброва О. Ю. Статистический анализ медицинских данных. Применение пакета прикладных программ STATISTICA / О. Ю. Реброва. - М. : Медиа Сорера, 2006 -312 c.

14. Принципы и критерии отнесения лекарственных средств к категории сильнодействующих и ядовитых : метод. реком. / И. М. Трахтенберг, В. А. Шаповалова, А. П. Викторов [и др.] // ГФЦ МОЗ Украины. - 2002. - 52 с.

\section{References}

1. Methodological recommendations on the basic rules of good manufacturing practice and quality control of veterinary drugs. Available at: http://www.vet.gov.ua/node/1819. Ukrainian.

2. Kosenko YuM, Zaruma LYe, Kalynovska LV, Stefanyshyn HS, Shkilnyk OS. [Manufacture of veterinary preparations according to the principles of Good Manufacturing Practice (GMP) - a strategy of quality assurance and compliance with international standards]. Scientific and technical bulletin of the Institute of Animal Biology and the State Scientific and Research Control Institute of Veterinary Preparations and Feed Additives. 2014;2-3: 340-5. Ukrainian.

3. On approval of the Procedure for conducting preclinical study of medicinal products and examination of materials for preclinical study of medicinal products. «Experimental study of the toxic effects of potential medicinal products»]. Nakaz MOZ Ukrainy № 944 vid 14.12.2009. Available at: http://zakon2.rada.gov.ua/laws/show/z0053-10. Ukrainian. 4. Polova Z., Almakayeva L., Nehoda T. Development of the composition of intramammary combined preparation based on silver citrate for veterinary. Czech and Slovak Pharmacy. 2017;66(5): 227-33.

5. Polova ZhM, Sakhanda IV, Dolaychuk OP. [Study of toxicological properties of silver citrate as an active pharmaceutical ingredient]. Zbirnyk nauk prats spivrob. NMAPO im. P.L. Shupyka. 2016;24(4): 290-5. Ukrainian.

6. Council Directive 2010/63/EU of 22 September 2010 on the protection of animals used for scientific purposes. $\mathrm{J}$ of the Eur Com L 276.2010; 33-79.

7. The procedure for conducting scientific experiments, experiments on animals. Official Bulletin of Ukraine. - Official edition. The normative document of the Ministry of Education, Science, Youth and Sports of Ukraine. Order from 01.03.2012 № 249. 2012; 24: 82. Ukrainian.

8. Kotsyumbas IYa, Malyk OH, Patereha IP. Preclinical studies of veterinary medicinal products [Доклінічні дослідження ветеринарних лікарських засобів]. Lviv: Triad plus; 2006. Ukrainian.

9. Stefanov O.V. Preclinical research of drugs: method. recommendations [Доклінічні дослідження лікарських засобів: метод. рекомендації] Kyiv: State pharmacolog center; 2001. Ukrainian.

10. Regulation on the Ethics Committee (bioethics) / (Normative document of the Ministry of Education, Sci-

ISSN 2312-0967. Фармацевтичний часопис. 2018. № 1 
Фармакологічні дослідження біологічно активних речовин Pharmacological researches of biologically active substances

ence, Youth and Sports of Ukraine. Order from 11.11.2012 № 1287): Regulatory and legal framework of the Ministry of Education and Science of Ukraine (official website) [Electronic resource]. - Available at: http://www.mon.gov.ua/ua/ activity/63/64/normativno-pravova-baza/.

11. Experimental study of the toxic effects of potential medicinal products / Preclinical studies of medicinal products: [method. Recom.]. [Експериментальне вивчення токсичної дії потенційних лікарських засобів / Доклінічні дослідження лікарських засобів: [метод. рек.] Kyiv: Avicenna 2001. Ukrainian.

12. Prozorovskiy VB. [Statistical processing of the results of pharmacological studies]. Psikhofarmak. i boil. 2007;7(34): 2090-120. Russian.
13. Rebrova OYu. Statistical analysis of medical data. Application of the STATISTICA software package [Статистический анализ медицинских данных. Применение пакета прикладных программ STATISTICA]. Moscow: Media Sphere, 2006. Russian.

14. Trahtenberg IM, SHapovalova VA, Viktorov AP, Shapovalov VV, Kovalenko VN, Halin NM, Abrosimov AS. Principles and criteria for assigning medicinal products to the category of potent and poisonous [Принципы $и$ критерии отнесения лекарственных средств к категории сильнодействующих и ядовитых]. State Pharmacological Center of the Ministry of Health of Ukraine. Kiev: 2002. Russian.

Отримано 06.12.2017

ISSN 2312-0967. Pharmaceutical review. 2018. № 1 